Fikrah: Jurnal Ilmu Aqidah dan Studi Keagamaan

issn 2354-6174 eissn 2476-9649

Tersedia online di: journal.iainkudus.ac.id/index.php/fikrah

Volume 9 Nomor 2 2021, (241 - 368)

DOI: 10.21043/fikrah.v8i1. 11986

\title{
Taqiyyah sebagai Peneguhan Harmoni dan Toleransi: Studi Aksiologi
}

\author{
Ulya \\ Institut Agama Islam Negeri Kudus, Indonesia \\ ulya@stainkudus.ac.id
}

\begin{abstract}
Every behavior cannot be freely valued, including religious behavior which has been carried out by the Shia community. This article examines the values inherent in the taqiyya carried out by the Shia community in Banjaran Village, Bangsri, Jepara Regency. The problems which are answered: how the concept of Taqiyya according to Shia community in Banjaran; how they practice it in socio-religious life; and what values are put forward from the implementation of taqiyya. Answering these problems based on a descriptive qualitative research. Data was collected from Shia figures, Shia believers, village chief and secretaries, as well as non-Shia residents. Data collection is carried out through non-participatory observation, semi-structured interviews, and documentation. Triangulation technique is used to check the credibility of the data. The analysis technique uses the interactive analysis model of Miles and Huberman. The results of the study indicate that taqiyya according to the Shia community in Banjaran is to refrain from revealing their Shia identity. They implement it, both in matters of worship and social interaction, when they are forced. Taqiyya is carried out by the Shia community in Banjaran within the framework of its function as an expression of obedience, as well as a strategy of self-defense and belief, as well as a strategy to adapt thus its existence is accepted and does not disturb society in general. This is where in the practice of taqiyya religious and social values are attached. These values contribute to the strengthening of harmony and tolerance in Banjaran.
\end{abstract}

Keywords: Religious values, social values, economic values, Shia, taqiyya 


\begin{abstract}
Abstrak
Setiap perilaku tak bisa bebas nilai karena antara perilaku dengan pelaku adalah dua hal yang tak bisa dipisahkan, termasuk perilaku Taqiyyah yang dilaksanakan oleh komunitas Syiah. Artikel ini menstudi nilai-nilai yang melekat dalam praktik Taqiyyah yang dilaksanakan oleh komunitas Syiah di Desa Banjaran, Kecamatan Bangsri, Kabupaten Jepara. Secara rinci, masalah yang akan dijawab dalam artikel ini adalah bagaimana pendapat komunitas Syiah di Desa Banjaran tentang Taqiyyah; bagaimana mereka mempraktikkannya dalam kehidupan sosial-keagamaan; dan nilai-nilai apa saja yang dikedepankan dari pelaksanaan Taqiyyah. Menjawab permasalahan tersebut digunakan desain penelitian kualitatif deskriptif. Data dikumpulkan dari sejumlah informan, meliputi: tokoh Syiah, penganut Syiah, kepala desa dan sekretaris desa, juga dari warga sekitar non-Syiah. Pengumpulan data dilakukan melalui observasi non-partisipatoris, wawancara semi terstruktur, dan dokumentasi. Untuk mengecek kredibilitas data digunakan teknik trianggulasi. Adapun teknik analisisnya menggunakan analisis interaktif model Miles and Huberman. Hasil studi menunjukkan bahwa Taqiyyah menurut komunitas Syiah di Desa Banjaran adalah menahan diri untuk tidak menampakkan identitas Syiahnya. Mereka mengimplementasikannya, baik dalam persoalan ibadah maupun dalam persoalan interaksi sosial, tatkala dalam keadaan terpaksa. Taqiyyah dilaksanakan oleh komunitas Syiah di Desa Banjaran sarat dengan nilai-nilai. Di samping sebagai ekspresi ketaatan, Taqiyyah sebagai strategi pertahanan hidup dan keyakinan, serta strategi untuk beradaptasi sehingga eksistensinya diterima dan tidak meresahkan masyarakat pada umumnya. Di sinilah dalam praktik Taqiyyah melekat nilai religius sekaligus nilai sosial, juga nilai ekonomi. Nilai-nilai tersebut, di antaranya, berkontribusi pada penguatan harmoni dan toleransi di Desa Banjaran, Kecamatan Bangsri, Kabupaten Jepara.
\end{abstract}

Kata Kunci: Nilai religius, nilai sosial, nilai ekonomi, Syiah, Taqiyyah

\title{
Pendahuluan
}

Komunitas Syiah adalah nama komunitas muslim yang meyakini bahwa Ali ibn. Abi Thalib lebih berhak menjadi khalifah pengganti Nabi Muhammad Saw. karena kedekatan keturunan dan relasi kekerabatannya. Demikian pula dengan anak cucunya yang disebut dengan ahl al-bayt (Thabathaba'i, 1989, hal. 32). Komunitas ini memiliki beberapa ajaran yang berbeda dari komunitas muslim pada umumnya, diantaranya adalah Taqiyyah. Taqiyyah adalah menyembunyikan sesuatu yang sesungguhnya di hadapan publik, termasuk menyembunyikan keimanan (Virani, 2011, hal. 99). Jika pada umumnya muslim dilarang menyembunyikan sesuatu dari yang sesungguhnya, baik dalam perkataan maupun perbuatan. Kejujuran adalah sesuatu yang sangat penting dalam ajaran Islam; namun Syiah justru memperbolehkan ketidakjujuran melalui ajaran tersebut. 
Semula Taqiyyah adalah sebuah solusi atas respon lokal berkaitan dengan persoalan kepemimpinan (Atabik, 2015, hal. 330), namun pada akhirnya menjadi ajaran yang bersifat universal. Sebagai ajaran yang universal, dia diberlakukan untuk semua komunitas Syiah, kapan saja dan dimana saja, termasuk komunitas Syiah di Desa Banjaran Kecamatan Bangsri Kabupaten Jepara sekarang ini. Yang seperti itu oleh Bourdieu disebut dengan doxa. Doxa adalah sudut pandang individu yang dominan yang menyatakan diri dan memberlakukan diri sebagai sudut pandang yang universal (Deal \& Beal, 2004; Haryatmoko, 2010). Keberlangsungan ajaran Taqiyyah sampai saat ini karena dia memiliki nilai-nilai tertentu melebihi sekedar ajaran yang harus diikuti. Studi yang melibatkan tentang nilai-nilai menjadi fokus kajian aksiologi. Aksiologi merupakan cabang filsafat yang membahas tentang segala yang berkaitan dengan nilai, seperti: esensi nilai, macam nilai, subyek yang memberi nilai, dan obyek yang diberi nilai (Kattsoff, 1992, hal. 327, 329).

Sejauh ini studi tentang Syiah dapat diklasifikasikan menjadi 4 (empat). Pertama, studi yang berkaitan dengan eksistensi Syiah dan karakteristiknya (Atabik, 2015; Dewi, 2016; Formichi, 2014; Hasim, 2012; Iryana et al., 2018). Dari studi tersebut dinyatakan bahwa Syiah lahir setelah peristiwa Perang Jamal dan Perang Shiffin (Atabik, 2015), sedangkan dia masuk ke Indonesia pertama kali bersamaan dengan proses islamisasi di nusantara (Hasim, 2012). Menurut Formichi, Syiah yang masuk di Indonesia adalah Syiah yang moderat sehingga ditemukan beberapa tradisinya serupa dengan tradisi Sunni sebagai komunitas muslim mayoritas di Indonesia (Formichi, 2014). Kedua, studi tentang Syiah yang berkaitan dengan beragam respons masyarakat terhadap eksistensinya (Amal, 2020; Farida, 2014; Kayane, 2020; Miichi \& Kayane, 2019). Dalam penelitian Farida ditemukan 2 (dua) macam respons masyarakat terhadap eksistensi Syiah. Sebagian menerimanya karena alasan pluralisme, toleransi, dan Hak Asasi Manusia (HAM), namun sebagian yang lain menolaknya dengan alasan pemurnian teologis dan penegasan ortodoksi (Farida, 2014). Ketiga, studi berkaitan dengan relasi Syiah dengan Sunni di wilayah tertentu(Aksa, 2018; Amaliyah, 2015; Sulaiman, 2017; Zahra \& Ghufron, 2018). Semua studi tersebut secara kebetulan mengambil Desa Banjaran sebagai lokasi penelitian. Lokasi yang juga menjadi lokus kajian ini. Menurut Zahra dan Ghufron, terjadi harmoni dalam hubungan Syiah - Sunni di Desa Banjaran karena masing-masing saling menjaga persaudaraan atas dasar kemanusiaan (ukhuwah insaniyah) (Zahra \& Ghufron, 2018), sebagaimana telah dicontohkan oleh nenek moyang mereka, Mbah Muhammad Arif (Amaliyah, 
2015). Keempat, studi yang berkaitan dengan ajaran-ajaran Syiah (Virani, 2011). Secara khusus, Virani telah mengeksplorasi praktik Taqiyyah yang dilaksanakan oleh komunitas Gupti Bhavnagar. Komunitas ini adalah para penganut Syiah Ismailiyah di India. Mereka melaksanakan Taqiyyah di tengahtengah masyarakat mayoritas beragama Hindu. Mereka menyembunyikan kemuslimannya dengan menampilkan diri mereka sebagai pemeluk Hindu (Virani, 2011).

Studi-studi terdahulu belum membahas tentang Taqiyyah yang dipersepsi dan dilaksanakan oleh komunitas Syiah di Desa Banjaran Kecamatan Bangsri Kabupaten Jepara secara khusus, apalagi dikaitkan dengan persoalan nilai. Oleh karena itu tulisan ini bermaksud melengkapinya dengan menghadirkan studi tentang perspektif aksiologi dalam praktik Taqiyyah oleh komunitas Syiah di sana. Tiga pertanyaan penelitian yang akan dikaji adalah bagaimana pendapat komunitas Syiah di Desa Banjaran Kecamatan Bangsri Kabupaten Jepara tentang Taqiyyah; bagaimana mereka mempraktikkannya dalam kehidupan sosial-keagamaan; dan nilai-nilai apa saja yang menjadi prioritas dari pelaksanaan Taqiyyah tersebut. Jawaban dari 3 (tiga) pertanyaan tersebut menjadi inti diskusi dalam studi ini.

Studi ini mengasumsikan bahwa ajaran Taqiyyah yang dilaksanakan oleh komunitas Syiah di Desa Banjaran, Kecamatan Bangsri, Kabupaten Jepara telah mengalami perluasan makna sejalan dengan tantangan yang dihadapi oleh mereka. Pandangan tersebut mempengaruhi keberlangsungan praktik Taqiyyah, baik dalam persoalan ibadah maupun dalam persoalan interaksi sosial. Selanjutnya ada satu hal yang menarik bahwa Taqiyyah yang dilaksanakan oleh mereka tidak sekedar memiliki nilai religius, terutama juga memiliki nilai sosial yang sangat fungsional dalam pencapaian harmoni dan toleransi.

\section{Kerangka Teoritik}

\section{Aksiologi sebagai Studi tentang Nilai}

Aksiologi adalah sebagai cabang filsafat yang dikembangkan untuk pertama kalinya pada pertengahan kedua abad ke-19 (Tinarso et al., 2018, hal. 399). Kata aksiologi, secara etimologi, berasal dari Bahasa Yunani, axios artinya nilai dan logos artinya teori atau ilmu (Endraswara, 2012, hal. 146; Tinarso et al., 2018). Aksiologi berarti teori atau ilmu tentang nilai (Zhang \& El-Gohary, 2016, hal. 2). Sedangkan secara definitif, menurut Katsoff bahwa aksiologi 
adalah ilmu pengetahuan yang menyelidiki hakikat nilai yang ditinjau dari sudut pandang kefilsafatan. Pembahasannya meliputi esensi nilai, macam nilai, subjek yang memberi nilai, dan objek yang diberi nilai (Kattsoff, 1992). Dari penjelasan di atas maka aksiologi sebagai sebuah studi yang berkaitan erat dengan persoalan nilai. Persoalan tentang nilai dimaksud meliputi apa yang baik, apa yang benar, apa yang berharga, apa yang sakral, dan apa yang indah atau bermakna (Peers, 2017, hal. 14).

Kata nilai sendiri memiliki arti yang bermacam-macam. Secara umum, menurut Katsoff, arti nilai ditinjau dari konteks pernyataan yang digunakan, sebagai berikut: 1). Nilai artinya guna, seperti kalimat: Paracetamol sangat berarti bagi orang yang sedang sakit panas; 2). Nilai artinya kualitas yang positif, seperti kalimat: Almari yang terbuat dari kayu jati bernilai lebih tinggi dibandingkan almari yang terbuat dari bahan plastik; 3). Nilai artinya kualitas yang menyebabkan orang mengambil sikap menyetujui atau mempunyai sifat nilai tertentu, seperti kalimat: Memberi pertolongan pada orang yang membutuhkan adalah baik; 4). Nilai artinya menanggapi sesuatu sebagai hal yang diinginkan atau sebagai hal yang menggambarkan nilai tertentu, seperti kalimat: Seorang guru memberi nilai baik untuk muridnya yang melaporkan hasil pekerjaannya tepat waktu (Kattsoff, 1992). Sedangkan secara khusus, nilai adalah suatu kualitas yang melekat pada sesuatu sehingga sesuatu itu menjadi bermanfaat bagi kehidupan manusia (Kaelan, 2005, hal. 41).

Kehidupan manusia sarat dengan beragam nilai. Setiap melakukan sesuatu, manusia pasti mempertimbangkan sekaligus dipengaruhi oleh nilainilai. Edelheim dalam studinya menyatakan bahwa semua manusia akan merencanakan masa depannya dan bertindak sesuai dengan nilai-nilai yang dipilihnya (Edelheim, 2020, hal. 1). Di sinilah nantinya muncul nilai prioritas, yaitu jenis nilai yang dipilih oleh seseorang karena dianggap lebih baik, lebih berguna, lebih indah, lebih benar,lebih penting dari pada nilai-nilai yang lain. Nilai prioritas ini antara manusia yang satu dengan manusia yang lain bisa tidak sama tergantung pada pengalaman dan kepentingannya.

Adapun beragam nilai dalam kehidupan manusia menurut Everet sebagaimana ditulis oleh Kaelan ada 8 (delapan), yaitu: 1. Nilai ekonomi, nilai yang berkaitan dengan kebutuhan ekonomi manusia; 2. Nilai kejasmanian, nilai yang berhubungan dengan aspek jasmani manusia; 3. Nilai hiburan, yaitu nilai yang berkaitan dengan permainan manusia untuk memperkaya kehidupan; 4. Nilai sosial, yaitu nilai yang berhubungan dengan kehidupan manusia dalam berkomunikasi dengan manusia lain; 5. Nilai watak, nilai yang 
berhubungan dengan kepribadian manusia; 6 . Nilai estetis, nilai yang berkaitan dengan keindahan; 7. Nilai intelektual; nilai yang berkaitan dengan aspek intelektual manusia; 8. Nilai religius, yaitu nilai yang berhubungan dengan keagamaan (Kaelan, 2005). Manusia diciptakan oleh Tuhan, maka dia adalah makhluk Tuhan. Seorang makhluk pasti membutuhkan Tuhan sebagai Khaliknya.

Kebutuhan manusia berhubungan dengan Tuhan telah memunculkan nilai religius. Selain sebagai makhluk Tuhan, manusia juga makhluk individu. Sebagai individu dia membutuhkan banyak hal mulai dari pemenuhan kebutuhan jasmani sampai kebutuhan aktualisasi diri. Dari sini muncul nilai ekonomi, nilai watak, nilai intelektual, dan lain-lain. Selanjutnya manusia juga makhluk sosial. Sebagai makhluk sosial maka ketergantungannya dengan manusia yang lain menjadi sebuah keniscayaan. Dari sinilah muncul nilai sosial. Nilai sosial atau nilai kolektif merupakan suatu kesatuan nilai-nilai yang paling menonjol dan dominan dalam kelompok yang mengatur dalam bertingkah laku (Scheler, 1997, hal. 102; Tinarso et al., 2018). Selanjutnya beberapa hal yang perlu diketahui saat manusia melakukan kegiatan penilaian, menurut Dewey seperti dikutip oleh Kattsoff, adalah sebagai berikut: 1). Pemberian nilai menyangkut perasaan, keinginan, dan sebagainya, tetapi juga menyangkut tindakan akal untuk menghubungkan sarana dengan tujuan; 2). Dalam melakukan penilaian, orang tidak seharusnya hanya menekankan pada pencapaian tujuan nilai tertentu saja, tetapi harus pula mempertimbangkan sarana yang digunakan. Contoh untuk mencapai nilai kebaikan hendaknya menggunakan sarana yang baik; 3).

Situasilah yang akan menciptakan nilai-nilai, maka nilai itu dinamis dan relatif, tidak abadi. Yang ada adalah nilai yang berubah-ubah yang tergantung pada keadaan yang meingkupinya; 4). Berkaitan dengan ketidaksepakatan nilai ada 2 (dua) macam, yaitu: ketidaksepakatan faktual dan ketidaksepakatan semu. Pertama, jika orang-orang bersepakat tentang tujuan yang hendak dicapai tetapi terjadi ketidaksepakatan mengenai cara-cara yang dilakukan untuk mencapai tujuan. Kedua, jika terdapat ketidaksepakatan tujuan yang akan dicapai (Kattsoff, 1992).

\section{Sejarah Kelahiran Syiah}

Arti kata Syiah adalah pengikut, pecinta, pembela terhadap ide atau individu atau kelompok tertentu (Shihab, 2007), sedangkan arti khususnya menunjuk kepada paham atau komunitas yang mengidolakan Ali ibn. Abi 
Thalib dan keturunannya (Dewan Redaksi Ensiklopedi Islam, 1997, hal. 5). Menurut Atabik dalam tulisannya bahwa Syiah berkeyakinan Ali adalah khalifah pilihan Nabi Muhammad Saw. dan dia adalah orang yang paling utama di antara para sahabat Nabi lainnya, yakni Abu Bakar. Umar ibn. Khattab, Usman ibn. Affan. Keutamaan ini disebabkan karena kedekatan keturunan dan relasi kekerabatannya dengan Nabi. Dia adalah orang yang paling besar jihadnya, paling banyak ilmunya, dan keluarganya adalah seutama-utama keluarga Arab (Atabik, 2015) . Alasan ini diperkuat dengan peristiwa Ghadir Khumm. Khumm adalah nama tempat di antara Madinah dan Makkah yang digunakan Nabi Saw. berkhotbah setelah menunaikan ibadah haji wada. Di tengah-tengah 120.000 sahabat yang hadir dan ikut dalam rombongan haji tersebut, Nabi mengatakan "Man kuntu mawlä fa 'aliyyun mawlä" (siapa yang menjadikan aku sebagai pemimpin maka Ali adalah pemimpin setelah aku). Pernyataan ini dinilai oleh Syiah sebagai simbol penyerahan kepemimpinan dari Nabi ke Ali (Zahra \& Ghufron, 2018) .

Dalam bingkai sejarah, benih kemunculan Syiah berawal setelah Nabi Saw. wafat (632 M). Wafatnya Nabi telah membuat umat Islam disibukkan dengan persoalan kekhalifahan. Kesibukan ini membuat pemakaman beliau tertunda (Nasution, 1986, hal. 3). Para sahabat Nabi bermusyawarah dan akhirnya menghasilkan kesepakatan politik. Kesepakatan tersebut mengangkat Abu Bakar sebagai pengganti Nabi dalam posisinya sebagai kepala negara. Namun saat dia dilantik sebagai khalifah, ternyata tidak semua sahabat dan umat Islam berjanji taat terhadapnya, termasuk Ali ibn. Abi Thalib. Berkembang 2 (dua) pendapat tentang penyebab Ali yang tidak ikut serta dalam pelantikan Abu Bakar. Pendapat pertama berpandangan karena Ali masih dalam suasana berkabung dengan wafatnya Nabi yang merupakan sepupu sekaligus mertuanya. Perdapat kedua menilai karena persoalan politik kepemimpinan (Madkour, 1995, hal. 88) .

Meski sebagian sahabat dan umat Islam tidak berjanji taat, Abu Bakar tetap menjalankan misinya sebagai kepala negara untukmerealisasikan kesepakatan. Akibatnya saat dia memerintah, wilayah Islam tidak sepenuhnya aman dan umat Islam tidak seluruhnya bersatu. Oleh karena itu dia mengambil kebijakan dengan menunjuk Umar ibn. Khattab sebagai penggantinya setelah dia wafat. Saat itu kaum muslimin menyetujuinya (Syukur, 2009, hal. 52). Selanjutnya kepemimpinan dipegang oleh Umar ibn. Khattab. Sistem pemerintahan yang dijalankannya mengalami kemajuan pesat. Dia mendirikan Dewan Pekerjaan Umum, membangun baitul mal, membuat mata uang, dan 
menciptakan kalenderisasi. Pemerintahan Umar berakhir setelah kematiannya yang tragis. Dia diserang secara tiba-tiba oleh seorang budak dari Persia bernama Abu Lu'luah di saat shalat berjamaah shubuh di Masjid Nabawi (Syukur, 2009).

Sepeninggal Umar, Usman ibn. Affan terpilih menjadi khalifah ketiga. Usman adalah pedagang yang kaya raya. Keluarganya terdiri dari orang-orang yang memiliki kekuasaan, kekayaan, dan wawasan yang luas tentang administrasi kenegaraan. Saat memerintah, Usman mengangkat beberapa anggota keluarganya menjadi gubernur. Tindakan politik yang dijalankan Usman seperti ini menjadikan dirinya ditinggalkan oleh sebagian sahabat yang dulu mendukungnya. Situasi ini dimanfaatkan oleh Abdullah ibn. Saba', seorang Yahudi yang baru masuk Islam. Dia menyebar fitnah dengan mencela Khalifah Usman dan memuji Ali ibn. Abi Thalib sebagai orang yang berhak menjadi khalifah. Propagandanya berhasil mempengaruhi sekelompok umat Islam tertentu yang berakibat menambah kebencian mereka terhadap Usman. Akhirnya mereka menyerbu Madinah dan membunuhnya (Syukur, 2009).

Setelah Usman wafat, mayoritas kaum muslimin meminta kesediaan Ali untuk menjadi khalifah. Saat dia memerintah, dia mendapatkan perlawanan dari Muawiyah, salah satu kerabat Usman, yang saat itu menjadi gubernur Syiria. Mula-mula Muawiyah menuntut Ali untuk mencari pelaku pembunuhan Usman tetapi berakhir dengan kudeta. Perlawanan Muawiyah terhadap Ali ini berlangsung di Shiffin sehingga disebut Peristiwa Shiffin. Dalam perang tersebut, sebenarnya pasukan Ali sudah hampir memperoleh kemenangan tetapi Amr ibn. Ash, ahli siasat perang dan orang kepercayaan Muawiyah, mengusulkan berdamai dengan mengangkat al-Quran. Peristiwa ini dikenal dengan tahkim atau arbitrase (Nasution, 1986). Merespon tahkim atau arbitrase ini pasukan Ali berbeda pendapat. Sebagian pasukan mendukung keputusan Ali yang menerima tahkim, sebagian lainnya mendesak Ali untuk menuntaskan perang sampai mendapatkan kemenangan, sebagian yang lain lagi tidak menentukan sikap (Abbas, 1989: 112-113).

Kelompok yang mendukung Ali inilah kemudian menjelma menjadi komunitas Syiah. Dari penjelasan tersebut, sesungguhnya semula Syiah lahir disebabkan karena faktor politik, tetapi dalam perkembangannya dia menjadi salah satu aliran teologi. Dia memiliki banyak ajaran dan tradisi yang berkaitan erat dengan persoalan keagamaan. Dalam studi Iryana, dkk dijelaskan beberapa ajaran dan tradisi keagamaan komunitas Syiah, yakni: 1). Keutamaan ahl albayt yaitu keluarga atau kerabat Nabi Saw.; 2). al-Bada' yaitu keyakinan tentang 
kemampuan Allah mengubah keputusan yang telah ditetapkan-Nya bukan karena maslahat seperti yang dipahami oleh banyak pihak; 3). Ritual 10 Asyura untuk memperingati Peristiwa Karbala, yaitu peristiwa kematian Imam Husain ibn. Ali yang dibunuh oleh Yazid ibn. Muawiyah; 4). Imāmah yaitu kepemimpinan Islam setelah Nabi berfungsi melanjutkan misi kenabian; 5). 'Ishmah yaitu keyakinan bahwa para imam Syiah itu sejajar dengan Nabi Saw. dan dijaga Allah dari dosa; 6). Mahdawiyyah yaitu keyakinan akan datangnya Imam Mahdi sebagai penyelamat kehidupan manusia di bumi di akhir zaman; 7). Marja'iyyah yaitu kembalinya kepemimpinan ahli hukum Islam; 8). Raj'ah yaitu keyakinan kebangkitan para imam sebagai bukti kekuasaan dan kebesaran Allah, bersamaan dengan munculnya Imam Mahdi di akhir zaman; 9). Tawassul yaitu memohon kepada Allah melalui Nabi dan imam-imam Syiah agar sebuah doa dikabulkan oleh Allah SWT; 10). Taqiyyah yaitu menyembunyikan sesuatu yang sesungguhnya dalam rangka mendapatkan keselamatan (Iryana et al., 2018).

\section{Taqiyyah antara Doktrin dan Strategi}

Sebagaimana telah dijelaskan di atas bahwa Taqiyyah merupakan salah satu ajaran Syiah. Secara etimologi, Taqiyyah berasal dari Bahasa Arab, ittaqā, yang artinya memelihara, takut (Yunus, 2015, hal. 33). Virani dalam studinya mengidentikkan dengan kitmān atau berbohong (Virani, 2011). Dari segi definitif, pihak internal Syiah mendefinisikannya sebagai penjagaan seseorang atas dirinya dengan menampakkan sesuatu yang berlawanan dengan apa yang ada dalam hatinya (Tim Ahlul Bait Indonesia: 2012:80). Sedangkan pihak eksternal Syiah, antara lain, menurut Sulaiman, Taqiyyah sebagai suatu kondisi dimana seseorang menyembunyikan agamanya atau amalan tertentu dalam situasi yang akan menimbulkan bahaya sebagai akibat dari adanya tindakan pihak lain yang menentangnya (Sulaiman, 2017) dan Virani mendefinisikannya dengan menyembunyikan sesuatu yang sesungguhnya di hadapan publik, termasuk menyembunyikan keimanan (Virani, 2011). Berdasarnya penjelasan ini maka inti dari Taqiyyah adalah tidak menampakkan atau merahasiakan sesuatu yang sebenarnya untuk menjaga diri dan keimanannya sehingga hidup menjadi bahagia. Dia tidak sekedar ajaran yang sifatnya normatif, tetapi dia juga sebuah strategi yang sifatnya politis. Taqiyyah sebagai ajaran sebagaimana dijelaskan oleh Virani karena dia mempunyai landasan doktrinal yang kokoh dalam al-Qur'an sebagaimana dalam QS. ali Imran 3:28 dan QS. al-Nahl 16:106 (Virani, 2011), sebagai berikut: 
Artinya: "Janganlah orang-orang mukmin menjadikan orang-orang kafir sebagai wali dengan meninggalkan orang-orang mukmin. Barangsiapa berbuat demikian, niscaya lepaslah ia dari wilayah Allah kecuali karena (siasat) memelihara diri dari sesuatu yang ditakuti dari mereka. Dan Allah memperingatkan kamu terhadap diri (siksa)-Nya. Dan hanya kepada Allah kembali (mu)" (QS. Āli 'Imrān, 3: 28) (Proyek Pengadaan Kitab Suci alQur'an Departemen Agama RI, 1994, hal. 80).

Menurut penafsiran Syiah sebagaimana dikatakan Mannan bahwa term tattaqun dalam ayat di atas yang berarti memelihara diri, menjaga diri, berasal dari akar kata yang sama dengan Taqiyyah yakni menyembunyikan dari sesuatu yang ditakuti(Mannan, 2012, hal. 198).

Artinya: "Barangsiapa yang kafir kepada Allah sesudah dia beriman (dia mendapat kemurkaan Allah), kecuali orang yang dipaksa kafir padahal hatinya tetap tenang dalam beriman (dia tidak berdosa), akan tetapi orang yang melapangkan dadanya untuk kekafiran, maka kemurkaan Allah menimpanya dan baginya azab yang besar" (Qs. Al-Nahl, 16: 106)(Proyek Pengadaan Kitab Suci al-Qur'an Departemen Agama RI, 1994).

Potongan ayat illa man ukriha wa qalbuhu mutmainnu bi al Iman (kecuali orang yang dipaksa kafir padahal hatinya tetap tenang dalam beriman) dalam ayat di atas dimaknai oleh Syiah sebagai orang yang melaksanakan Taqiyyah. Taqiyyah berkaitan dengan sikap atau tindakan tidak menampakkan keimanannya pada Allah dalam keadaan dipaksa.

Berdasarkan ayat-ayat tersebut maka Syiah meyakini bahwa Taqiyyah menjadi bagian dari syariat agama yang harus dilaksanakan dalam situasi tertentu. Begitu urgennya Taqiyyah sehingga Syiah menyatakan bahwa "Sesungguhnya sembilan dari sepersepuluh syariat Islam adalah terdapat dalam masalah Taqiyyah, tiada agama (Islam) bagi setiap orang yang tidak memiliki sifat Taqiyyah" (Mannan, 2012).

Selanjutnya Taqiyyah sebagai strategi politis karena ajaran ini menjadi populer saat komunitas Syiah merahasiakan keberadaannya untuk menyelamatkan diri dari tindakan kekerasan dan pengejaran yang dulu pernah dilakukan oleh penguasa Umayyah dan penguasa Abbasiyah. Dicatat dalam sejarah bahwa meskipun Perang Shiffin telah selesai dan Muawiyah telah memegang kendali pemerintahan Islam, dia dan pasukannya tetap menganggap kelompok pendukung Ali ibn. Abi Thalib dan ahl al-bayt adalah musuh utamanya. Tak mau mendapatkan rintangan dalam menjalankan roda pemerintahan, Muawiyah dan keturunannya memerangi pendukung dan keturunan Ali dengan kejam. Pertempuran Karbala dan terbunuhnya al-Husain 
ibn. Ali ibn. Abi Thalib di tangan Yazid ibn. Muawiyah merupakan salah satu tragedi politik terbesar yang menyisakan trauma berkepanjangan dari para pendukung Ali. Selanjutnya saat pemerintahan Bani Muawiyah jatuh di tangan Bani Abbasiyah, ternyata perlakuan Bani Abbasiyah terhadap keturunan Ali tidak kalah kejamnya. Bagai sebuah peribahasa, keluar dari mulut singa tetapi masuk ke mulut harimau. Menghadapi pengalaman demi pengalaman yang pahit ini, Syiah berpendapat bahwa mereka harus membentengi diri dengan Taqiyyah (Hasim, 2012; Madkour, 1995). Taqiyyah dinilai sebagai satu-satunya cara yang diimplementasikan untuk menghindari kesewenang-wenangan dan kekejaman rezim otoritas yang berkuasa saat itu.

Berdasarkan penjelasan tersebut, maka sejatinyaajaran dan tradisi Taqiyyahpada awal kelahirannya berkaitan dengan 2 (dua) faktor, yakni dalam rangka menjalankan ajaran agama dalam perspektif Syiah sebagai faktor internal dan sebagai bentuk pertahanan diri melawan penindasan sebagai faktor eksternal.

\section{Metode}

Artikel ini adalah hasil riset lapangan yang menggunakan desain penelitian kualitatif deskriptif. Dengan desain ini berbagai fenomena sosial dideskripsikan secara detail dan mendalam. Adapun lokasi penelitiannyadi Desa Banjaran, Kecamatan Bangsri, Kabupaten Jepara, Provinsi Jawa Tengah. Di lokasi ini tercatat kurang lebih dihuni 400 orang penganut Syiah dari sejumah 150 Kepala Keluarga (JZ (Sekretaris Desa), 2020a). Dari jumlah tersebut ditentukan sumber datanya berdasarkan pertimbangan penguasaan informasi atas masalah yang diteliti atau disebut dengan purposive sampling (Sugiyono, 2005, hal. 53-54). Sumber data dipilih dan ditentukan dari tokoh Syiah di Desa Banjaran dan para penganut Syiah di sana. Mereka ini adalah sebagai sumber data primer. Sedangkan sumber data sekunder dipilih dari kepala desa dan sekretaris desa, juga beberapa warga sekitar yang non-Syiah.

Selanjutnya pengumpulan data dilakukan melalui observasi aktif nonpartisipatoris, wawancara semi terstruktur, dan dokumentasi. Untuk mengecek kredibilitas data dilakukan teknik trianggulasi, baik trianggulasi sumber data, trianggulasi teknik pengumpulan data, dan trianggulasi waktu. Setelah didapatkan sejumlah data yang diperlukan, data dianalisis menggunakan analisis interaktif model Miles and Huberman. Sebagaimana dijelaskan oleh Sugiyono, analisis data dimaksud dilakukan melalui langkahlangkah berikut: 1). reduksi data yaitu merangkum, memilih dan memilah 
beragam data yang telah didapatkan, lalu memfokuskan pada data-data pokok dan penting yang sesuai dengan tema kajian; 2).display data yaitu menyajikan data, baik dalam bentuk uraian singkat, bagan, hubungan antar kategori, flowchart, dan sejenisnya, sehingga data bisa dibaca dan dipahami dengan mudah; dan 3). Kesimpulan atau verifikasi data yaitu beragam data yang telah direduksi dan disajikan diambil kesimpulannya. Kesimpulan itu mula-mula masih sangat kabur, bisa jadi diragukan kesahihannya. Oleh karena itu kesimpulan senantiasa harus diverifikasi selama penelitian berlangsung. Kegiatan penyimpulan dilakukan dengan terlebih dahulu menafsirkan data dan menguraikannya secara jelas sehingga akhirnya didapatkan temuan yang bisa dipertanggungjawabkan. Secara keseluruhan penelitian ini dilaksanakan selama 2 (bulan) bulan, yaitu Juli sampai Agustus 2020.

\section{Urgensi Taqiyyah dalam merajut Harmoni bagi Golongan Syiah}

Taqiyyah dipahami sejalan dengan problem atau tantangan yang dihadapi sehingga Taqiyyah sebagai ajaran yang muncul pada masa lalu tetap fungsional di masa sekarang ini. Artikel membahas tentang Taqiyyah yang dipahami oleh komunitas Syiah di Desa Banjaran Kecamatan Bangsri Kabupaten Jepara, bagaimana mereka mempraktikkannya, dan nilai-nilai apa yang melekat dalam pelaksanaan Taqiyyah tersebut.

\section{Sekilas tentang Syiah di Desa Banjaran}

Banjaran adalah salah satu nama desa di Kecamatan Bangsri, Kabupaten Jepara, Provinsi Jawa Tengah, Indonesia. Nama desa ini diambil dari seorang tokoh lokal yang bernama Ki Banjar. Dia adalah kekasih Dewi Wiji. Dewi Wiji adalah anak dari Ki Gede Bangsri. Di samping Ki Banjar, ada orang lain yang juga menyukai Dewi Wiji. Namanya Suroghoto. Dia berniat mempersunting Dewi Wiji, tetapi Dewi Wiji menolaknya. Dewi Wiji melarikan diri dari rumah untuk meminta perlindungan kepada Ki Banjar. Suroghoto menyusulnya dan bertemulah dia dengan Ki Banjar. Keduanya bertarungdi suatu tempat memperebutkan cinta dari Dewi Wiji. Pertarungan berakhir dengan kematian Ki Banjar. Tempat kematian Ki Banjar itu kemudian diabadikan menjadi sebuah nama desa, yaitu Desa Banjaran (Aksa, 2018; TR (Kepala Desa), 2020).

Desa ini cukup ramai. Mobilitas masyarakat keluar - masuk desa relatif lancar karena sudah tersedia jalan beraspal yang menghubungkan desa tersebut dengan desa-desa lainnya. Di sana sudah tersedia pula transportasi umum yang bisa dimanfaatkan dengan mudah oleh masyarakat. Jarak antara 
Desa Banjaran ini dengan Jakarta, ibu kota Indonesia, sekitar $500 \mathrm{~km}$; jarak antara desa ini dengan Semarang, ibu kota provinsi sekitar $70 \mathrm{~km}$; jarak desa ini dengan Jepara, ibu kota kabupaten, sekitar $20 \mathrm{~km}$; dan jarak antara desa ini dengan Bangsri, ibu kota kecamatan, adalah $3 \mathrm{~km}$. Desa ini memiliki luas wilayah 510.072 ha, bertopografi dataran, berada <500m di atas permukaan laut.Desa Banjaran berbatasan langsung dengan Desa Banjaragung pada Bagian Utara, berbatasan dengan Desa Srikandang di Bagian Timur, berbatasan dengan Desa Trengguli pada Bagian Selatan, dan berbatasan dengan Desa Bangsripada Bagian Barat. Desa ini terdiri dari 13 RW dan 48 RT (JZ (Sekretaris Desa), 2020b).

Desa Banjaran berpenduduk 9.500 jiwa lebih. Mereka menganut paham keagamaan yang berbeda-beda, sebagian menganut paham Sunni dan lainnya berpaham Syiah. Mereka yang berpaham sunni mengikuti 2 (dua) organisasi keagamaan yang berbeda juga, yaitu Nahdhatul Ulama dan Muhammadiyah. Masyarakat yang berafiliasi Nahdhatul Ulamasekitar $50 \%$, Muhammadiyah sekitar 15\%, dan penganut Syiah sekitar 35\%. Syiah di Desa Banjaran menyebar hampir di seluruh wilayahnya, namun yang paling banyak terdapat di RW 01 yakni di RT 02, 03 dan 04 di Dukuh Candi atau Sendangsari dan diRW12 Dukuh Montro (JZ (Sekretaris Desa), 2020e). Untuk menjalankan aktivitas peribadatan, komunitas Syiah di Banjaran memiliki musalla khusus yang bernama Musalla al-Husaini (JZ (Sekretaris Desa), 2020c).

Sejarah masuknya Syiah di desa ini tidak bisa dilepaskan dari sejarah masuknya Islam di Indonesia(AL (Tokoh Syiah), 2020c). Asal usul dan formasi awal komunitas Syiah di Indonesia memang masih diperdebatkan, namun diyakini komunitas ini bukanlah pendatang baru (Miichi dan Kayane, 2019: 3). Gelombang pertama, Syiah masuk di Indonesia bersamaan dengan masuknya Islam pertama kali, yaitu 1 Muharram 225H/840 M. Kebanyakan tokoh Syiah Arab, Persia, dan Hindi berlabuh di Bandar Perlak Aceh dan membangun kerajaan Islam di sana (Hasymy, 1989, hal. 146-156). Eksistensi Syiah di Aceh ditunjukkan dengan adanya tokoh-tokoh ulama terkemuka, seperti: Hamzah Fansuri, Syamsuddin ibn. Abdullah as Sumatrani, Nuruddin ar-Raniry, Burhanuddin, dan Ismail ibn. Abdullah, namun setelah Aceh dipegang oleh penguasa Sunni maka sejak saat itu para tokoh dan penganut Syiah tidak lagi menampakkan diri (Hasim, 2012).

Gelombang selanjutnya, pasca revolusi Iran pada tahun 1979 yang dipimpin oleh Ayatullah Ruhullah Khumaini, Syiah menjadi idola baru di dunia termasuk di Indonesia. Banyak buku-buku tentang Syiah yang masuk ke 
Indonesia, tetapi juga banyak pihak yang mengkaunternya terutama dari komunitas Sunni sebagai komunitas muslim mainstream (Hasim, 2012; Latief, 2008, hal. 302). Meskipun demikian penyebaran Syiah di sini tidak selalu berkaitan dengan revolusi Iran tersebut. Banyak ulama muslim lokal, sebagian besar keturunan Arab, yang secara diam-diam telah menyebarkan ajaran dan kebiasaan-kebiasaan Syiah. Beberapa ulama dimaksud antara lain: Abdul Qadir Bafagih, Husein al-Habsyi, Jalaluddin Rahmat, Umar Shahab, dan lainnya (Latief, 2008). Selanjutnya berdirinya organisasi Ikatan Jamaah Ahlul Bait (IJABI) di Bandung pada tahun 2000 (www.ijabi.or.id) dan organisasi Ahlul Bait Indonesia (ABI) di Jakarta pada tahun 2010 (www.ahlulbaitindonesia.or.id) menjadi penanda bangkitnya kembali Syiah yang telah sekian lama menyembunyikan dirinya. Respons kebanyakan masyarakat Indonesia cenderung negatif, maka terjadilah penyerangan dan pengusiran terhadap komunitas Syiah di berbagai wilayah, seperti: di Batang (2000), di Bondowoso (2006), di Lombok (1008), di Madura (2012), dan lain-lain (Amin et al., 2013, hal. 62).

Dikisahkan oleh AL, Syiah masuk di Desa Banjaran, Kecamatan Bangsri, Kabupaten Jepara dibawa oleh seorang Habib bernama Abdul Qadir Bafagih.Dia berasal dari Tuban tetapi menikah dengan seorang perempuan Jepara. Semula dia dikenal sebagai seorang yang beraliran Sunni. Dia menjadi Syiahsetelah terjadi revolusi Islam di Iran tahun 1979. Tokoh ini mulai belajar buku-buku Syiah yang didapatkannya dari berbagai negara yang berhaluan Syiah (AL (Tokoh Syiah), 2020a). Ajaran Syiah diajarkannyamelalui pengajian di Pondok Pesantren Al- Khairat yang didirikannya pada tahun 1980. Pondok pesantren ini berlokasi di Desa Kauman, Kecamatan Bangsri, Kabupaten Jepara. Lokasinya kira-kira $3 \mathrm{Km}$ dari Desa Banjaran. Kharisma Habib Abdul Qadir Bafaqih yang santun dalam berdakwah berpengaruh besar dalam mengenalkan ajaran Syiah di Desa Banjaran. Tetapi sayang, sekarang ini Pesantren AlKhairat sebagai embrio hadirnya Syiah di Jepara, khususnya di Desa Banjaran, sudah tak bisa dilihat kiprahnya karena penerus Habib Abdul Qadir Bafaqih tidak ada lagi. Adapun pusat lembaga pendidikan keagamaan Syiah di Jepara sekarang ini terpusat di Pesantren Darut Taqrib di Desa Krapyak, Kecamatan Tahunan, Kabupaten Jepara (AL (Tokoh Syiah), 202ob).

Mula-mula paham Syiah diterima kurang baik oleh mayoritas masyarakat Desa Banjaran yang mayoritas berpaham Sunni, tetapi berkat jasa Habib Abdul Qadir Bafagih ini akhirnya mereka hidup berdampingan dalam satu ikatan warga Desa Banjaran. Generasi selanjutnya menerima keberadaan 
komunitas Syiah karena banyak faktor. Satu sisi karena pewarisan tradisi dari orang tua yang telah menerima komunitas Syiah secara terbuka; hubungan kekeluargaan akibat pernikahan beda madzhab/aliran, Sunni-Syiah; karakteristik mata pencaharian warga Banjaran sebagai pekerja menjadikan mereka tidak memiliki waktu luang untuk mencari-cari kejelekan orang lain (JZ (Sekretaris Desa), 2020d; Observasi Penerimaan Paham Keagamaan Syiah di Masyarakat, 2020). Sedangkan di sisi lain karena kemampuan beradaptasi dari komunitas Syiah dengan warga Desa Banjaran sehingga seringkali sulit membedakan mana penganut Syiah dan mana penganut sunni, terutama bagi para pendatang baru di desa ini (Observasi terkait Kemampuan Adaptasi Penganut Syiah, 2020).

\section{Taqiyyah menurut Komunitas Syiah di Desa Banjaran}

Komunitas Syiah di Desa Banjaran sebagai kelompok minoritas yang hidup berdampingan dengan komunitas Sunni sebagai kelompok mayoritas, baik yang berafiliasi Nahdhatul Ulama maupun Muhammadiyah. Interaksi kedua komunitas yang berbeda tersebut nyaris tanpa konflik sebagaimana disampaikan dalam beberapa studi sebelumnya (Aksa, 2018; Amaliyah, 2015; Sulaiman, 2017; Zahra \& Ghufron, 2018). Kondisi tersebut dikuatkan dengan pengamatan peneliti saat berkali-kali di lapangan (Observasi terkait Taqiyyah Menurut Komunitas Syiah di Desa Banjaran, 2020) juga denganpernyataan JZ, Sekretaris Desa. Dalam sebuah wawancara, dia mengatakan :

"Masyarakat di sini kesadarannya bagus, akhirnya faktor resiko konflik itu tidak ada. Sejak saya lahir sampai sekarang belum pernah menemui adanya semacam cekcok. Jika konflik yang sifatnya individual ya wajar wajar saja..." (JZ (Sekretaris Desa), 202of).

TR, Kepala Desa, juga menyampaikan pengalaman yang sama. Dia berkata bahwa :

"Banyak mahasiswa yang melakukan penelitian tentang toleransi di Desa Banjaran ini karena mengetahui masyarakat dan penganut Syiah di sini rukun-rukun saja...toleransi di sini cukup bagus karena masyarakat tidak merasa terganggu dengan adanya Syiah. Baik-baik saja dari dulu” (AL (Tokoh Syiah), 2020i).

Masyarakat Desa Banjaran yang mayoritas penganut Sunni tidak terganggu dengan hadirnya Syiah. Pengalaman-pengalaman di atas relevan dengan pernyataan $\mathrm{AL}$, seorang tokoh Syiah. Hasil wawancara dengannya merepresentasikan bahwa komunitas Syiah di Desa Banjaran menekankan 
pada pentingnya persaudaraan di tengah perbedaan paham keagamaan ini. Untuk mencapai persaudaraan maka diajarkan cara komunikasi yang baik dan sikap selalu menahan diri. AL menyatakan bahwa :

"Perbedaan paham atau ideologi beragama dalam masyarakat sini sudah biasa. Yang penting komunikasi dan kesadaran menahan diri dimulai dari diri sendiri. Perbedaan bukan penghalang untuk tidak berbaur satu sama lain, namun dalam perbedaan tetap menjaga rasa persaudaraan satu dengan yang lain" (AL (Tokoh Syiah), 202oh).

Pernyataan AL ini maka ada 2 (dua) kata kunci penting dari pihak komunitas Syiah agar mereka diterima oleh masyarakat pada umumnya di Banjaran. Dua kata itu adalah komunikasi dan menahan diri.

Mempraktikkan komunikasi yang baik dan sikap menahan diri sebagaimana disampaikan oleh AL berkaitan erat dengan ajaran Taqiyyahsebagaimana dipahami komunitas Syiah di Desa Banjaran. Taqiyyah dipahami oleh AL sebagai sikap menampakkan sesuatu yang tidak diyakini dan menutup sesuatu yang diyakini karena kondisi membahayakan (AL (Tokoh Syiah), 2020d). Dalam bahasa yang berbeda, NSR, salah seorang penganut Syiah di Desa Banjaran, menyatakan bahwa Taqiyyah itu sikap sementara untuk tidak mengakui apa yang sesungguhnya diimani, tidak mengatakan apa yang sebenarnya menjadi pendapatnya, dan tidak melakukan apa yang seharusnya menjadi amalannya. Kondisi tersebut diperbolehkan sebagai upaya untuk menyelamatkan nyawa diri dan keluarga serta untuk kemaslahatan umat Syiah pada umumnya (NSR (Penganut Syiah), 2020d). Berdasarkan pendapat mereka ini tersimpulkan bahwa Taqiyyah bagi komunitas Syiah di Desa Banjaran dipahami sebagai upaya menahan diri untuk tidak menampakkan yang sebenarnya karena alasan dan tujuan tertentu.

Menurut AL, Komunitas Syiah di Banjaran mengikuti ajaran ini karena berkomitmen pada tradisi yang telah dilakukan pada masa Nabi Muhammad masih hidup. AL menceritakan sebuah kisah sahabat Nabi yang bernama Usamah. Dikisahkan bahwa orang tua Usamah dibunuh karena menolak menyembah berhala, Latta dan Uzza. Usamah sendiri selamat karena dia mengaku beriman kepada Latta dan Uzza, meskipun dalam hatinya dia telah beriman kepada Allah.Usamah mengadu kepada Nabi Saw.: "Wahai Rasulullah, apakah saya telah kafir dengan mengingkari Allah Swt.". Nabi balik bertanya kepada Usamah : "Apakah hatimu masih beriman ?". "Wahai Rasulullah, saya masih beriman" Jawab Usamah (AL (Tokoh Syiah), 2020j). 
Taqiyyah dipahami oleh penganut Syiah di Banjaran bukan ajaran yang eksklusif Syiah. Kelompok lain juga punya ajaran seperti itu hanya mereka menyebutnya berbeda. NSR berargumentasi :

"Taqiyyah itu bukan hanya ajaran Syiah. Semua paham keagamaanmemiliki konsep Taqiyyah. Namanya saja yang berbeda. Pada kelompok lain ada konsep ketika kondisi darurat, yaitu kondisi dimana sesuatu yang haram bisa menjadi halal. Taqiyyah diperbolehkan para nabi ketika seseorang terancam jiwanya." (NSR (Penganut Syiah), 2020c).

Dalam hal yang sama, AL juga mengisahkan tentang Taqiyyah yang pernah dilakukan oleh para ulama terdahulu. AL menceritakan Peristiwa Mihnah (inkuisisi) pada masa al-Makmun, salah satu khalifah pada pemerintahan Bani Abbasiyah. Saat terjadi peristiwa itu sebagian ulama melakukan Taqiyyah karena adanya intimidasi yang dilakukan oleh khalifah yang berpaham Mu'tazilah tentang kemakhlukan al-Qur'an. Secara lahir mereka terpaksa menerima pemikiran itu, meskipun keyakinan mereka menolaknya (AL (Tokoh Syiah), 2020j).

Komunitas Syiah di Desa Banjaran menolak pihak lain yang memandang negatif ajaran Taqiyyah. Taqiyyah seringkali diidentikkan dengan munafik seperti pemahaman salah seorang warga Desa Banjaran (SH, Penganut Sunni, 15 Agustus 2020). Taqiyyah bagi mereka bukan sesuatu yang negatif tetapi positif. Jika Taqiyyahadalah menyembunyikan sesuatu yang baik, sementara munafik sebagai menyembunyikan sesuatu yang tidak baik dengan berpurapura baik.(NSR (Penganut Syiah) \& UM (Penganut Syiah), 2020). Taqiyyah itu mengikuti filosofi bunglon dan justru sebagai bukti kecerdasan Syiah. Kata AL:

"Taqiyyah ibarat bunglon. Bunglon adalah hewan yang dapat menyesuaikan diri sesuai lingkungannya, dapat berkamuflase, dan berubah warna saat merasa terancam oleh musuh. Misalkan gini kalau mbaknya memakai pakaian tertentu itu dicurigai dan itu membahayakan diri mbaknya, kira-kira mbaknya akan melepas dan mengganti dengan pakaian lain kan ?. Terus pakaian tadi tidak dibuang tapi disembunyikan. Ini kan logis. Beda lagi misalkan kalau mbaknya diterima menggunakan pakaian yang berbeda maka mbaknya tidak perlu melepas dan menyembunyikan pakaiannya. Taqiyyah itu seperti itu. Selama tidak membahayakan, Taqiyyah itu tidak perlu. Taqiyyah hanya dibutuhkan saat keadaan mendesak. Taqiyyah itu cerdasnya orang membaca kondisi dan keadaan"(AL (Tokoh Syiah), 202og). 
Taqiyyah sebagai ajaran Syiah tidak dilaksanakan secara secara rutin dan kontinyu seperti layaknya salat yang dilaksanakan 5 (lima) kali sehari dalam waktu-waktu tertentu atau puasa pada Bulan Ramadan, dan seterusnya. Taqiyyah dilaksanakan pada kondisi yang menurut mereka membahayakan, baik membahayakan keyakinannya, dirinya, keluarganya, dan lain-lain. Adapun ukuran saat kondisi dinilai bahaya ternyata relatif dan sangat individual. Oleh karena itu meskipun sama-sama penganut Syiah di Desa Banjaran, bisa jadi si A melaksanakan Taqiyyah tetapi si B tidak karena mereka berbeda dalam menilai sebuah kondisi bahaya atau tidak (Observasi Terkait Pelaksanaan Ajaran Taqiyyah pada Komunitas Syiah, 2020). Dalam konteks ini NSR juga telah mengatakan :

"Melaksanakan Taqiyyah atau tidak tergantung diri masing-masing dalam menghadapi dan menilai bahaya. Semua tergantung pada sikap diri masing-masing"(NSR (Penganut Syiah), 2020a).

Berdasarkan pernyataan-pernyataan di atas maka Taqiyyah dilaksanakan bukan tanpa alasan dan bukan tanpa tujuan atau kegunaan. Bagi komunitas Syiah di Desa Banjaran, Taqiyyah melebihi dari sekedar ajaran yang disakralkan, yaitu untuk menjaga agama dan keyakinan. Dalam Taqiyyah memuat aspek-aspek duniawi yang bersifat profan, seperti: menjaga nyawa, menjaga diri dan keluarga, memudahkan menyesuaikan diri dengan lingkungan, menjaga persatuan dan persaudaraan, dan untuk kemaslahatan umat lainnya. UM menyatakan bahwa:

"Taqiyyah itu sebagai perlindungan diri saat terjadi ancaman dan bahaya karena tidak semua orang menerima Syiah maka dari itu Taqiyyah digunakan untuk melindunginya saat hal yang tidak diinginkan terjadi kepadanya(UM (Penganut Syiah), 2020a) .

Senada dengan UM, NSR juga menyatakan hal yang kurang lebih sama :

"Taqiyyah digunakan dalam Syiah pada saat merasa terancam atau merasa dalam keadaan bahaya. Karena tidak semua orang menerima perbedaan dan tidak semua orang menerima Syiah. Maka dari itu Syiah menggunakan Taqiyyah bertujuan untuk kemaslahatan umat agar dapat diterima di masyarakat. Dikarenakan masyarakat pada umumnya sulit menerima perbedaan" (NSR (Penganut Syiah), 202ob).

Akhirnya Taqiyyah itu macam-macam. Menurut penjelasan AL, Taqiyyah ditinjau dari sisi tujuannya menjadi 2 (dua) bagian, yaitu Taqiyyah makhafatiyah dan Taqiyyah mudaratiyah Taqiyyah makhafatiyah adalah melakukan Taqiyyah karena kawatir bahaya. AL mencontohkan 
menyembunyikan agama atau keyakinannya di tengah agama atau aliran keagamaan lain; sedangkan Taqiyyah mudaratiyah adalah Taqiyyah yang ditujukan untuk menjaga perasaan orang yang berbeda dengannya, demi terjalinya hubungan baik antar keluarga atau umat yang berbeda untuk menghindarkan fitnah yang dapat meresahkan masyarakat atau demi terealisasinya persatuan umat Islam, seperti: melaksanakan praktik keagamaan tertentu yang tidak menjadi amalannya karena sedang berada di tengah mayoritas yang melaksanakan amalan tersebut. (AL (Tokoh Syiah), 2020e). Sebagai catatan bahwa pengertian Taqiyyah makhafatiyah adalah menyembunyikan keyakinan sebab takut. Hal ini berdasarkan pada kata makhafatiyah yang secara etimologi berasal dari akar kata khäfa berarti takut (Munawir, 1984, hal. 818-819). Sedangkan Taqiyyah mudaratiyah berarti menyembunyikan keyakinan sebab terpaksa. Secara etimologi kata mudaratiyah berasal dari kata darra yang artinyabahaya, terpaksa, darurat (Edelheim, 2020).

Berdasarkan paparan tersebut maka dapat disimpulkan beberapa hal penting bahwa secara konseptual, Taqiyyah menurut komunitas Syiah Desa Banjaran adalah sebuah ajaran menahan diri untuk tidak menampakkan yang sebenarnya dengan tujuan tertentu. Tujuan tertentu dimaksud, di samping untuk mengimplementasikan doktrin, juga sebagai upaya melindungi keyakinan, diri dan keluarga dari bahaya yang ditimbulkan pihak lain, juga sebagai sarana memudahkan komunikasi dan interaksi untuk tercapainya persatuan dan persaudaraan umat Islam secara keseluruhan. Tentang bagaimana komunitas Syiah di Desa Banjaran ini mengimplementasikan ajaran Taqiyyah sebagaimana paparan di bawah ini.

\section{Praktik Taqiyyah oleh Komunitas Syiah di Desa Banjaran}

Seperti telah dijelaskan di atas bahwa Taqiyyah dipahami oleh komunitas Syiah di Desa Banjaran sebagai upaya menahan diri untuk tidak menampakkan sikap atau perilaku tertentu yang berbeda dengan mayoritas untuk sebuah kemaslahatan keyakinan, diri, dan umat. Doktrin ini tidak hanya diyakini saja tetapi juga diimplementasikan dalam kehidupan nyata meskipun sifatnya situasional, relatif, dan individual. Situasional artinya dilaksanakan jika kondisi dinilai tidak aman atau membahayakan; relatif artinya penilaian sebuah kondisi itu aman atau bahaya tidak memiliki ukuran yang universal; individual karena penentuan perlu tidaknya melakukan Taqiyyah tergantung pada setiap individu bagaimana dia menilai dan menghadapi kondisi tersebut. 
Sejauh diketahui, komunitas Syiah di Desa Banjaran melaksanakan Taqiyyah dalam beberapa hal, baik dalam persoalan peribadatan maupun dalam hubungan antar manusia, meskipun ada informan yang menolak adanya praktik Taqiyyah di desa ini, sebagaimana yang AL nyatakan:

“... Akan tetapi berbeda dengan yang ada di sini. Masyarakat sudah memahami segala bentuk perbedaan dan dapat menerima perbedaan. Di sini tidak perlu berTaqiyyah, tidak perlu ada yang disembunyikan karena Syiah diterima baik oleh masyarakat. Kalau semua masyarakat Desa Banjaran pada dasarnya menerima Syiah jadi buat apa berTaqiyyah", ucap AL(AL (Tokoh Syiah), 202of).

Beberapa contoh kasus Taqiyyah teridentifikasi: pertama, Taqiyyah dalam persoalan peribadatan seperti pelaksanaan adzan (panggilan salat). Syiah memiliki tradisi adzan yang berbeda dengan adzan yang selama ini dilaksanakan. Kalimat kesaksian (Asyhadu an la ilaha illa Allāh wa asyhadu anna Muhammad Rasul Allah) dan seruan untuk mendapatkan kebahagiaan (hayya ala al-falah) dalam tradisi adzan versi Syiah menjadi kalimat Asyhadu an lā ilāha illa Allah wa Asyhadu anna Muhammad Rasul Allah wa anna Aliyy Waliyya Allah dan hayya ala al khayr al-amal. Di musalla al-Husaini, tempat beribadah komunitas Syiah di Desa Banjaran tidak mengumandangkan adzan seperti itu melalui pengeras suara yang bisa didengar oleh masyarakat luas, tetapi cukup melalui salon dalam musalla saja atau kadang-kadang dilakukan tanpa pengeras suara (Observasi Terkait Pelaksanaan Ibadah di Musalla Tanpa Pengeras Suara, 2020). Perilaku semacam ini dimaksudkan agar tidak menimbulkan keresahan masyarakat sebagaimana perkataan UM:

"Kami sadar kalau keyakinan kami ada perbedaannya dengan masyarakat sini pada umumnya, tetapi kami berusaha tidak membuat keresahan di tengah masyarakat..." (UM (Penganut Syiah), 202od).

Begitu juga terkait pelaksanaan salat. Selain adzan, Syiah juga memiliki cara salat yang khas, seperti: tidak melipat tangan di bawah dada saat berdiri membaca surat al-fätihah dan surah pendek, tidak pula membaca kalimat āminn di akhir bacaan surat al-fātihah (ta'mīn), menggunakan batu sebagai tempat sujud (turbah). Praktik salat semacam ini dilaksanakan oleh komunitas Syiah di Desa Banjaran saat mereka melakukan salat berjamaah di Musalla al-Husaini. Sedangkan tatkala mereka salat di musalla atau masjid-masjid pada umumnya, respon mereka berbeda beda. Sebagian dari mereka merasa lebih aman jika mereka menyembunyikan identitas Syiahnya saat salat di masjid non-Syiah. UM menyatakan: 
"Kalau di rumah atau di musalla (maksudnya: Musalla al-Husaini), salatnya ya tentunya sesuai dengan keyakinan kami. Tapi kalau di tempat lain untuk sementara kami mengikuti bagaimana mereka salat. Untuk hati-hati saja karena tidak semua orang menerima keyakinan seperti kami-kami ini" (UM (Penganut Syiah), 2020e)

Sebagian yang lain tidak merasa perlu melaksanakan Taqiyyah saat salat, dimanapun tempatnya, seperti yang dilakukan oleh NSR. Dia berkata:

"Ada daerah-daerah tertentu yang tidak mau menerima Syiah. Misalnya ada teman-teman Syiah yang tidak kuat betul dengan kondisi tertentu maka dia salatnya sedakep (maksudnya : kedua tangan dilipat di bawah dada). Saya pribadi kalau salat dimana-mana ya tidak sedakep (maksudnya : kedua tangan lurus). Misal nanti ada yang bertanya, saya akan jawab Syiah" (NSR (Penganut Syiah), 2020a).

Kedua, taqiyyah dalam interaksi sosial. Sebuah pengalaman yang dirasakan saat penelitian adalah sulitnya membedakan mana masyarakat penganut Syiah dan mana yang bukan, terutama tatkala terjadi berbagai kegiatan sosial keagamaan di tengah masyarakat, misalnya : dalam acara pernikahan, memperingati hari kemerdekaan RI, dalam peringatan hari besar Islam, dan lain-lain (Observasi Terkait Taqiyyah Dalam Interaksi Sosial, 2020). Mereka membaur dalam satu wadah sebagai warga Desa Banjaran. "Sesama warga masyarakat Desa Banjaran maka sudah seharusnya saling bekerja sama dan bersaudara, urusan keyakinan itu urusan pribadi masing-masing" (AB (Penganut Sunni) et al., 2020).

Komunitas Syiah di Desa Banjaran tidak pernah membuka atau menonjolkan identitas Syiahnya dalam komunikasi antar warga, apalagi tatkala berhadapan dengan pendatang baru. Biasanya, para pendatang baru di Desa Banjaran mengetahui identitas Syiah - tidaknya seseorang warga Desa Banjaran adalah tatkala mereka mendirikan salat (AB (Penganut Sunni), 2020). Sikap atau perilaku seperti ini, disadari atau tidak disadari, komunitas Syiah di Desa Banjaran telah mengimplementasikan Taqiyyah. Problem ini juga telah mengakibatkan kesulitan mendapatkan data yang tepat tentang jumlah komunitas Syiah yang berada di desa ini.

Selanjutnya implementasi Taqiyyah dalam kegiatan ekonomi dicontohkan oleh AL. Ada seorang penganut Syiah memiliki sebuah toko. Toko tersebut satu-satunya tempat mencari nafkah. Namun ada pihak keluarga yang memaksanya kembali ke keyakinan sebelumnya. Jika tidak mau, dia diancam dan tokonya ditutup. Jika toko ditutup maka penganut Syiah ini tidak akan 
memperoleh pendapatan yang selama ini digunakan untuk menghidupi diri dan keluarganya. Hal ini dapat membahayakan diri serta keluarganya. Oleh karena itu penganut Syiah tersebut disarankan untuk mengikuti kemauan yang diinginkan keluarga dengan tanpa meninggalkan yang telah diyakininya ( $\mathrm{AB}$ (Penganut Sunni) et al., 2020).

\section{Nilai Penting Taqiyyah Menurut Komunitas Syiah Banjaran}

Seperti sudah disampaikan di atas bahwa sikap dan perilaku manusia itu tidak akan pernah bisa netral. Di antaranya, ada pengalaman, juga kepentingan yang menentukan sikap yang dipilih dan perilaku yang dilakukan oleh seseorang. Semua manusia akan merencanakan masa depannya dan bertindak sesuai dengan nilai-nilai yang dipilihnya. Begitu kata Edelheim (Kaelan, 2005). Ini berarti antara sikap dan perilaku seseorang di satu sisi dan nilai pada sisi yang lain menjadi dua hal tidak bisa dipisahkan. Taqiyyah sebagai salah satu ajaran yang dilakukan oleh komunitas Syiah Desa Banjaran juga memiliki karakteristik tersebut.

Nilai yang mendorong sikap dan perilaku manusia, termasuk Taqiyyah, itu macam-macam. Menurut Everet sebagaimana ditulis oleh Kaelan bahwa bermacam nilai itu adalah nilai ekonomi, nilai kejasmanian, nilai hiburan atau rekreatif, nilai sosial; nilai watak atau kepribadian, nilai estetis, nilai intelektual, dan nilai religius (Prima, 2015).

Sudah dipaparkan bahwa Taqiyyah bagi komunitas Syiah di Desa Banjaran menjadi perilaku yang fungsional. Dipahami dan dilakukan Taqiyyah untuk berbagai macam alasan dan tujuan. Taqiyyah menjadi ajaran Syiah yang sarat dengan nilai-nilai. Berdasarkan hal ini maka ditemukan bahwa pelaksanaan Taqiyyah oleh komunitas Syiah di Desa Banjaran memiliki 3 (dua) nilai yang ditekankan secara sekaligus, yaitu nilai religius, nilai sosial, dan nilai ekonomi.

Taqiyyah memiliki nilai religius, yaitu berkaitan dengan keagamaan, hubungan manusia dengan Tuhan. Dalam konteks ini melaksanakan Taqiyyah dalam rangka mengekspresikan ketaatan pada ajaran dan untuk kepentingan keberlangsungan agama atau keyakinannya dari tekanan mayoritas serta melindungi nyawa dari pihak-pihak yang mengancamnya,sebagaimana dinyatakan UM(UM (Penganut Syiah), 2020c). 
Taqiyyah juga memiliki nilai sosial yang berkaitan dengan komunikasi dalam hubungan manusia dengan manusia lainnya. Melaksanakan Taqiyyah untuk tujuan sebuah kehidupan yang nyaman di tengah masyarakat. Secara umum Taqiyyah dilaksanakan oleh komunitas Syiah di Banjaran untuk menghindari konflik dan mendorong terciptanya kerukunan dan persaudaraan, memudahkan menyesuaikan diri dengan masyarakat sekitar sehingga eksistensinya bisa diterima, dan untuk menjaga persatuan dan persaudaraanantara lain dinyatakan oleh NSR (NSR (Penganut Syiah) \& AL (Tokoh Syiah), 2020).

Taqiyyah memiliki nilai ekonomi berkaitan dengan upaya mempertahankan hidup, seperti melaksanakan Taqiyyahuntuk mempertahankan diri dan keluarga dari tekanan ekonomi (NSR (Penganut Syiah) \& AL (Tokoh Syiah), 2020).

Uraian di atas membuktikan bahwa nilai-nilai yang melekat dalam Taqiyyah terlahir berdasarkan kepentingan dan tantangan hidup yang dihadapi komunitas Syiah di sana. Komunitas Syiah di Desa Banjaran adalah pendatang baru di desa ini yaitu di sekitar tahun 1980-an di tengah mayoritas warga Desa Banjaran yang muslim, yang aktif dalam organisasi keagamaan Nahdhatul Ulama dan Muhammadiyah, organisasi yang merepresentasikan kesunnian. Di samping untuk menjaga agama dan diri, Taqiyyah yang dilaksanakan oleh komunitas Syiah di Desa Banjaran bernilai agar mereka bisa diterima eksistensinya oleh masyarakat luas maka komunitas Syiah di sini menjauhi sikap konfrontasi. Pendahulu Syiah di Desa Banjaran ini, Habib Abdul Qadir Bafaqih, telah mencontohkan berdakwah dengan santun (AL (Tokoh Syiah), 2020c). Hasilnya sebagian warga banjaran menerima kehadiran Syiah sebagai saudara, namun dalam beberapa hal komunitas Syiah tetap berhati-hatikarena menyadari posisinya sebagai minoritas (UM (Penganut Syiah), 2020b) .

\section{Simpulan}

Artikel ini menjawab 3 (tiga) masalah utama, yaitu tentang pendapat komunitas Syiah di Desa Banjaran tentang Taqiyyah; bagaimana mereka mempraktikkannya; dan nilai-nilai yang dikedepankan dari pelaksanaan Taqiyyah tersebut. Setelah melalui pembahasan sebagaimana dipaparkan di atas maka kesimpulannya: 1). Taqiyyah menurut komunitas Syiah di Desa Banjaran adalah menahan diri untuk tidak menampakkan identitas Syiahnya, utamanya, untuk untuk menghindari konflik demi menjaga persatuan dan keharmonisan. 2). Mereka mengimplementasikannya, baik dalam peribadatan 
maupun dalam interaksi sosial. Mereka melakukannya saat keadaan terpaksa dan secara situasional sebagai ekspresi kehati-hatian mereka sebagai minoritas yang hidup di tengah mayoritas sunni. 3). Taqiyyah seperti itu dilaksanakan oleh mereka sarat dengan nilai-nilai, yaitu nilai religius berkaitan dengan ekspresi ketaatan, untuk mempertahankan agama dan keyakinan; nilai sosial yaitu sebagai strategi beradaptasi sehingga eksistensinya diterima, tidak meresahkan masyarakat, dan menghindari konflik;serta nilai ekonomi yaitu berkaitan denganupaya mempertahankan hidup.

Berdasarkan temuan di atas, Taqiyyah yang dikenal sebagai salah satu ajaran Syiah yang muncul dan popular kira-kira pada abad ke-7H,dulunya dia adalah tradisi yang pernah dilaksanakan tatkala Nabi Muhammad masih hidup. Selanjutnya dia dipahami secara dinamis oleh para penganutnya. Jika pada awalnya dia dipahami sebagai suatu kondisi menyembunyikan ke-Islaman dengan berpura-pura kufur; dalam perkembangannya, dia merujuk pada kondisi tidak menampakkan ke-Syiahan untuk melindungi diri dari berbagai kekerasan dan penindasan; sekarang ini khususnya oleh komunitas Syiah di Desa Banjaran, dia dipahami sebagai menahan diri tidak melakukan perilaku yang berbeda untuk mempertahankan agama, mempertahankan hidup, dan menghindari konflik demi menjaga persatuan dan keharmonisan. Dalam konteks ini terdapat temuan penting dan menarik bahwa Taqiyyah yang dilaksanakan oleh komunitas Syiah di Desa Banjaran tidak sekedar bernilai religius, tetapi bernilai sosial yang sangat fungsional dalam pencapaian toleransi dan harmonisasi di Desa Banjaran.

Terakhir, sesungguhnya diskusi tentang agama dan praktik keberagamaan, salah satunya adalah tentang Taqiyyah yang dilaksanakan oleh komunitas Syiah, menjadi bidang yang menarik untuk diteliti, tetapi juga sangat sensitif. Oleh karena itu data yang obyektif dan mendalam telah membantu mendapatkan kesimpulan dalam studi ini. Studi ini hanya membahas konsep dan praktik Taqiyyah menurut komunitas Syiah di Desa Banjaran Kecamatan Bangsri Kabupaten Jepara dan nilai-nilai penting yang melekat di dalamnya, padahal banyak hal yang bisa diungkapkan dari studi tentang Taqiyyahini. Harapan selanjutnya akan ada studi tentang Taqiyyah dari perspektif lain guna memperkaya kajian bidang sosial keagamaan. 


\section{Referensi}

AB (Penganut Sunni). (2020). Wawancara Terkait Penonjolan Identitas Diri.

AB (Penganut Sunni), JZ (Sekretaris Desa), \& AL (Tokoh Syiah). (2020). Wawancara Terkait Implementasi Taqiyyah Dalam Interaksi Sosial.

Aksa, A. H. (2018). Harmoni Sosial Sunni dan Syi'ah di Dukuh Candi Desa Banjaran Jepara: Sebuah Pendekatan Fungsionalisme Struktural. Jurnal Sosiologi Agama, 12(1), 47-66. https://doi.org/https://doi.org/10.14421/jsa.2018.121-03

AL (Tokoh Syiah). (2020a). Wawancara Asal Usul Masuknya Syiah di Desa Banjaran.

AL (Tokoh Syiah). (2020b). Wawancara Pusat Lembaga Pendidikan Keagamaan Syiah di Jepara.

AL (Tokoh Syiah). (2020c). Wawancara Sejarah Masuknya Syiah di Desa.

AL (Tokoh Syiah). (2020d). Wawancara Terkait Ajaran Taqiyyah Bagi Komunitas Syiah di Desa Banjaran.

AL (Tokoh Syiah). (2020e). Wawancara Terkait Jenis Taqiyyah.

AL (Tokoh Syiah). (2020f). Wawancara Terkait Nilai Penting Taqiyyah Bagi Komunitas Syiah Banjara Yakni Untuk di Terima Eksistensinya dan Telah di Contohkan Pendahulunya.

AL (Tokoh Syiah). (2020g). Wawancara Terkait Pemahaman Bahwa Taqiyyah mengikuti Filosofi Bunglon Sebagai Bentuk Kecerdasan Syiah.

AL (Tokoh Syiah). (2020h). Wawancara terkait Respon Paham Keagamaan Lain terhadap Syiah.

AL (Tokoh Syiah). (2020i). Wawancara terkait Taqiyyah menurut Komunitas Syiah di Desa Banjaran.

AL (Tokoh Syiah). (2020j). Wawancara Tokoh Syiah Yang Menyebutkan Bahwa Taqiyyah Sudah di Lakukan Pendahulu.

Amal, M. K. (2020). Anti-Shia mass mobilization in Indonesia's democracy: godly alliance, militant groups and the politics of exclusion. Indonesian Journal of Islam and Muslim Societies, 10(1), 25-48. https://doi.org/10.18326/ijims.v10i1

Amaliyah, E. I. (2015). Harmoni di Banjaran: Interaksi Sunni-Syiah. Harmoni, 14(2), 81-96.

Amin, M., Ilyas, Y., Sam, I., \& T, A. (2013). Mengenal dan Mewaspadai Penyimpangan Syiah di Indonesia (M. Baharun (ed.)). Al-Qalam.

Atabik, A. (2015). Melacak Historisitas Syiah (Asal-Usul, Perkembangan dan AliranAlirannya). Fikrah, 3(2), 325-348.

Deal, W. E., \& Beal, T. K. (2004). Theoryfor Religious Studies. Routledge.

Dewan Redaksi Ensiklopedi Islam. (1997). Ensiklopedi Islam (5 ed.). Ichtiar Baru Van Hoeve.

Dewi, O. S. (2016). Syiah: Dari Kemunculannya Hingga Perkembanganya di Indonesia. 
Jurnal Studi Al-Qur'an, 12(2), 217-237.

https://doi.org/doi.org/10.21009/JSQ.012.2.06

Edelheim, J. (2020). How should tourism education values be transformed after 2020 ? Tourism Geographies, 22(3), 547-554.

Endraswara, S. (2012). Filsafat Ilmu : Konsep, Sejarah, dan Pengembangan Metode Ilmiah. Caps.

Farida, A. (2014). Respon Organisasi Massa Islam terhadap Syiah di Bandung Jawa Barat. Penamas, 27(2), 156-176.

Formichi, C. (2014). From Fluid Identities to Sectarian Labels : A Historical Investigation of Indonesia's Shi'i Communities. Al-Jāmi'ah, 52(1), 101-126. https://doi.org/10.14421/ajis.2014.521

Haryatmoko. (2010). Dominasi Penuh Muslihat, Akar Kekerasan dan Diskriminasinya. Gramedia.

Hasim, M. (2012). Syiah: Sejarah Timbul dan Perkembangannya di Indonesia. Harmoni, 11(4), 22-33.

Hasymy, A. (1989). Sejarah Masuk dan Berkembangnya Islam di Indonesia. PT. alMaarif.

Iryana, W., Lubis, N. H., Zakaria, M. M., \& Sofianto, K. (2018). The Existence of Shia in Indonesia between Tradition and Power of Government. Paramita, 28(2), 125136. https://doi.org/http://dx.doi.org/10.15294/paramita.v28i2.12912

JZ (Sekretaris Desa). (2020a). Wawancara Penganut Syiah di Desa Banjaran.

JZ (Sekretaris Desa). (2020b). Wawancara Profil Desa Banjaran.

JZ (Sekretaris Desa). (2020c). Wawancara Tempat Peribadatan.

JZ (Sekretaris Desa). (2020d). Wawancara Terkait Penerimaan Paham Keagamaan Syiah di Masyarakat.

JZ (Sekretaris Desa). (2020e). Wawancara terkait Persentasi Penganut Paham Keagamaan.

JZ (Sekretaris Desa). (2020f). Wawancara terkait Taqiyyah pada Komunitas Syiah di Desa Banjaran.

Kaelan. (2005). Metode Penelitian Kualitatif Bidang Filsafat: Paradigma Bagi Pengembangan Penelitian Interdisipliner Bidang Filsafat, Budaya , Sosial, Semiotika, Sastra, Hukum dan Seni. Paradigma.

Kattsoff, L. O. (1992). Pengantar Filsafat Sebuah Buku Pegangan untuk Mengenal Filsafat. Tiara Wacana.

Kayane, Y. (2020). Understanding Sunni-Shi'a Sectarianism in Contemporary Indonesia : A different Voice from Nahdlatul Ulama under Pluralist Leadership. Indonesia and the Malay World, 48(140), 78-96. https://doi.org/10.1080/13639811.2020.1675277

Latief, H. (2008). The Identity of Shi'a Sympathizers in Contemporary Indonesia. Journal of Indonesian Islam, 2(2), 300-335. 
Madkour, I. (1995). Aliran dan Teori Filsafat Islam. Bumi Aksara.

Mannan, A. (2012). Syi'ah Tantangan Umat Islam Indonesia. Pondok Pesantren AlFalah Ploso Kediri.

Miichi, K., \& Kayane, Y. (2019). The Politics of Religious Pluralism in Indonesia: The Shi'a Response to the Sampang Incidents of 2011-12. TRaNS: Trans -Regional and -National Studies of Southeast Asia, 8(1), 51-64.

https://doi.org/10.1017/trn.2019.12

Munawir, A. W. (1984). Kamus al-Munawwir Arab-Indonesia Terlengkap. Pustaka Progressif.

Nasution, H. (1986). Teologi Islam Aliran-aliran Sejarah Analisa Perbandingan. Universitas Indonesia (UI-Press).

NSR (Penganut Syiah). (2020a). Wawancara Pelaksanaan Taqiyyah di Komunitas Syiah.

NSR (Penganut Syiah). (2020b). Wawancara Terkait Aspek-aspek dalam Ajaran Taqiyyah.

NSR (Penganut Syiah). (2020c). Wawancara Terkait Pemahaman Taqiyyah bagi Penganut Syiah di Desa Banjaran bahwa Ajaran tersebut bukan ajaran eksklusif Syiah.

NSR (Penganut Syiah). (2020d). Wawancara Terkait Taqiyyah bagi Komunitas Syiah di Desa Banjaran.

NSR (Penganut Syiah), \& AL (Tokoh Syiah). (2020). Wawancara Terkait Nilai Penting Taqiyyah Bagi Komunitas Syiah Banjaran.

NSR (Penganut Syiah), \& UM (Penganut Syiah). (2020). Wawancara Terkait Penolakan Komunitas Syiah Terhadap Pihak Lain Yang Memandang Negatif Ajaran Taqiyyah.

Observasi Penerimaan Paham Keagamaan Syiah di Masyarakat. (2020).

Observasi terkait Kemampuan Adaptasi Penganut Syiah. (2020).

Observasi Terkait Pelaksanaan Ajaran Taqiyyah pada Komunitas Syiah. (2020).

Observasi Terkait Pelaksanaan Ibadah di Musalla Tanpa Pengeras Suara. (2020).

Observasi Terkait Taqiyyah Dalam Interaksi Sosial. (2020).

Observasi terkait Taqiyyah Menurut Komunitas Syiah di Desa Banjaran. (2020).

Peers, D. (2017). Engaging Axiology : Enabling Meaningful Transdisciplinary Collaboration in Adapted Psysical Activity. Human Kinetics, 35(3), 267-284.

Prima, D. (2015). Penafsiran Ucapan Selamat Natal dan Prinsip-prinsip Toleransi Beragama Dalam Tafsir Al-Misbah. Analytica Islamica, 4, 1-26.

Proyek Pengadaan Kitab Suci al-Qur'an Departemen Agama RI. (1994). Al-Qur'an dan Terjemahnya. Indah Press.

Scheler, M. (1997). Formalism in Ethics and Non-Formal Ethics of Values a New Attempt toward the Foundation of an Ethical Personalism. Northwestern 


\section{University Press.}

Shihab, M. Q. (2007). Sunnah-Syiah Bergandengan Tangan! Mungkingkah?: Kajian atas Konsep Ajaran dan Pemikiran. Lentera Hati.

Sugiyono. (2005). Memahami Penelitian Kualitatif. Alfabeta.

Sulaiman. (2017). Relasi Sunni - Syiah: Refleksi Kerukunan Umat Beragama di Bangsri Kabupaten Jepara. Panangkaran, 1(1), 19-36.

Syukur, F. (2009). Sejarah Peradaban Islam. PT.Pustaka Rizki Putra.

Thabathaba'i. (1989). Islam Syiah: Asal-Usul dan Perkembangannya. Pustaka Utama Grafiti.

Tinarso, P., Supartiningsih, \& Hadi, H. (2018). Aksiologi Nilai Egaliter Budaya "Arek Suroboyo". al-Ulum, 18(2), 395-416.

TR (Kepala Desa). (2020). Wawancara Sekilas Tentang Syiah di Desa Banjaran.

UM (Penganut Syiah). (2020a). Wawancara Terkait Aspek-aspek yang Terdapat Dalam Ajaran Taqiyyah.

UM (Penganut Syiah). (2020b). Wawancara Terkait Hasil Atas Implementasi Ajaran Syiah.

UM (Penganut Syiah). (2020c). Wawancara Terkait Nilai Penting Taqiyyah Bagi Komunitas Syiah Banjaran.

UM (Penganut Syiah). (2020d). Wawancara Terkait Pelaksanaan Peribadatan.

UM (Penganut Syiah). (2020e). Wawancara Terkait Pelaksanaan Solat.

Virani, S. N. (2011). Taqiyya and Identity in a South Asian Community. The Journal of Asian Studies, 70(1), 99 - 139. https://doi.org/10.1017/S0021911810002974

Yunus, M. (2015). Kamus Arab-Indonesia. Mahmud Yunus wa Dzurriyyah.

Zahra, F., \& Ghufron, M. (2018). Strategi Pengembangan Nilai-Nilai Toleransi dalam Relasi Sosial Sunni-Syi'ah di Perkampungan Candi Desa Banjaran-Jepara. Islamic Review, 7(2), 158-173.

Zhang, L., \& El-Gohary, N. M. (2016). Discovering Stakeholder Values for AxiologyBased Value Analysis of Building Projects. Journal of Construction Engineering and Management, 142(4), 1-15. 